\title{
ANALISIS KATETERISASI TERHADAP KEJADIAN INFEKSI DI SALURAN KEMIH PADA PASIEN RUANG RAWAT INAP RSU IMELDA PEKERJA INDONESIA (IPI) MEDAN TAHUN 2017
}

\author{
1. Roby Gultom , 2. Pontianus Famaugu \\ 1. Dosen Prodi S1Keperawatan, STIKes Imelda, Jalan Bilal Nomor 52 Medan; \\ 2. Alumni STIKes Imelda \\ E-mail: ${ }^{1}$ roby.gultom@gmail.com
}

\begin{abstract}
ABSTRAK
Kateterisasi perkemihan adalah tindakan memasukkan selang karet atau plastik melalui uretra ke dalam kandung kemih untuk mengeluarkan air kemih yang terdapat di dalamnya. Infeksi saluran kemih diduga berhubungan dengan faktor risiko yaitu pemasangan kateterisasi perkemihan Penelitian ini bertujuan untuk mengidentifikasi kejadian infeksi di saluran kemih pada pasien yang sudah terpasang katetersiasi di Ruang Rawat Inap RSU Imelda Pekerja Indonesia (IPI) Medan Tahun 2017. Penelitian dilakukan pada April 2017 dengan pendekatan cross sectional. Populasi dalam penelitian ini adalah perawat pelaksana di Rumah Sakit Imelda Medan dan sampel sebanyak 13 orang yang ditentukan dengan menggunakan teknik purposive sampling. Analisis statistik yang digunakan uji chi-square. Hasil analisis univariat, didapat bahwa bahwa kateterisasi yang dilakukan oleh perawat mayoritas baik sebanyak 10 orang (76,92\%), kejadian infeksi saluran kemih sebanyak 2 orang (15,38\%), sedangkan 11 orang $(84,62 \%)$ tidak terkena infeksi saluran kemih. Hasil analisis bivariat menunjukkan bahwa pemasangan kateter yang baik yaitu 10 orang dan tidak menyebabkan kejadian infeksi saluran kemih, sedangkan prosedur kateterisasi yang buruk yaitu 3 orang. Dari 3 orang tersebut, 2 orang terinfeksi saluran kemih dan 1 orang tidak terinfeksi saluran kemih. Dari hasil uji chi-square diatas antara pemasangan kateter dengan kejadian infeksi saluran kemih didapat nilai $P=0.005(P<0,05)$ artinya ada hubungan antara pemasangan kateter dengan kejadian infeksi saluran kemih. Disarankan bagi perawat untuk meningkatkan pengetahuan tentang prosedur pemasangan dan perawatan kateter.
\end{abstract}

Kata kunci: Kateterisasi, Infeksi Saluran Kemih.

\section{PENDAHULUAN}

Infeksi saluran kemih merupakan infeks i yang paling sering didapat dari rumah sakit dan jumlahnya $40 \%$ dari 2 juta kejadian infeksi nosokomial pertahun (UTIS are the most common nosocomial infections). Tingginya potensi infeksi saluran kemih tersebut berkaitan dengan penggunaan kateter menetap > 48 jam. Untuk menegakka $\mathrm{n}$ kejadian infeksi saluran kemih adalah dengan ditemukannya bakteri dalam urin bakteriuria (Brooks, 2007). Infeksi kandung kemih terjadi ketika ada bakteri atau Mikroorganisme lainnya, melekat pada pembukaan uretra dan berkembang biak (Dephi, 2014).

Infeksi saluran kemih diduga berhubung an dengan faktor risiko yaitu pemasangan kateterisasi perkemihan. Kateterisasi perkemi han adalah tindakan memasukkan selang karet atau plastik melalui uretra ke dalam kandung kemih untuk mengeluarkan air kemih yang terdapat di dalamnya. Pemasanga $\mathrm{n}$ kateter biasanya dilakukan sebagai tindakan untuk memenuhi kebutuhan eliminasi pada pasien yang tidak memiliki kemampuan untuk mobilisasi seperti pasien pembedahan, pasien dengan kondisi kronis atau lemah yang membuatnya tidak memiliki kemampuan untuk melakukan mobilisasi secara aktif. Tindakan ini dinilai berbahaya karena dapat menyebabkan masuknya organisme ke dalam kandung kemih (Kozier et all 2010).

Menurut Gruendemann dan Fernsebner (2006) penyebab utama infeksi saluran kemih pada pasien yang dirawat di rumah sakit adalah pemasangan kateter. Pendapat yang sama juga dikemukakan oleh Boss Meyer et all (2004) bahwa infeksi saluran kemih dapat disebabkan oleh pemasangan kateter indwelling (kateter yang dipakai untuk beberapa hari atau minggu). Infeksi saluran kemih sering berkaitan dengan penggunaan 
kateter urin yaitu penggunaan kateter memungkinkan jalur masuk mikroba kedalam saluran kemih sehingga semakin lama kateter terpasang maka peluang kateter terkontaminasi oleh mikroba semakin besar dan peluang pasien terkontaminasi mikroba juga semakin besar sebab kateter dapat mengiritasi lapisan kulit saluran kemih dan juga merupakan jalur masuk yang menghubu ngkan antara dunia luar dengan bagian dalam saluran kemih Hal ini yang menyebabkan mudahnya akses mikroba masuk kesaluran kemih.

Menurut Craven (2000), dan Furqon (2003) infeksi setelah pemasangan kateter dapat terjadi karena kuman dapat masuk kedalam kandung kemih dengan jalan berenang melalui lumen kateter. Pengurangan lama pemakaian kateter dapat menurunkan terjadinya infeksi saluran kencing. Pemasang an kateter akan menurunkan sebagian besar daya tahan pada saluran kemih bagian bawah dengan menyumbat saluran di sekeliling uretra, mengiritasi mukosa kandung kemih dan menimbulkan jalur masuknya kuman ke dalam kandung kemih. Pada pasien yang menggunakan kateter, mikroorganisme dapat menjangkau saluran kemih melalui tiga lintasan utama: yaitu dari uretra ke dalam kandung kemih pada saat kateterisasi; melalui jalur dalam lapisan tipis cairan uretra yang berada di luar kateter ketika kateter dan membran mukosa bersentuhan; dan cara yang paling sering melalui migrasi ke dalam kandung kemih di sepanjang lumen internal kateter setelah kateter terkontaminasi (Gruendemann dan Fernsebner 2006).

Mashita, (2011) menyatakan untuk mengurangi kejadian infeksi saluran kemih akibat pemasangan kateter menetap perlu dilakukan penggantian kateter 3-4 hari sekali. Namun pasien yang menggunakan kateter $>3$ hari memiliki peluang untuk mengalami infeksi saluran kemih dibandingk an dengan pasien yang menggunakan kateter $\leq 3$ hari, ada pengaruh antara perawatan kateter dengan kejadian Infeksi Saluran Kemih pada pasien yang menggunakan kateter menetap berarti bahwa pasien dengan pemasangan kateter yang kateternya tidak dirawat secara rutin setiap hari mempunyai peluang untuk mengalami kejadian infeksi saluran kemih dibandingkan dengan pasien dengan pemasangan yang kateternya dirawat secara rutin Putri dkk (2011).

Hasil studi pendahuluan di RSUD Ulin Banjarmasin pada pasien rawat inap yang terpasang kateter perbulan adalah 183 pasien dari jumlah tersebut 7 orang atau $3,8 \%$ mengalami infeksi saluran kemih. Rata rata lama pemasangan kateter adalah 3-7 hari (Nopi Arisandy, 2013). Mencermati permasal ahan di atas terdapat dugaan bahwa lama pemasangan kateter dapat menjadi penyebab infeksi saluran kemih pada pasien yang menjalani rawat inap sehingga peneliti memandang perlu untuk melakukan penelitian tentang "Analisis Kateterisasi Terhadap Kejadian Infeksi Di Saluran Kemih Pada Pasien di Ruang Rawat Inap RSU Imelda Pekerja Indonesia (IPI) Medan Tahun 2017’.

\section{Rumusan Masalah}

Rumusan masalah pada penelitian ini menganalisis pemasangan kateterisasi terhadap Kejadian Infeksi Di Saluran Kemih Pada Pasien di Ruang Rawat Inap RSU Imelda Pekerja Indonesia (IPI) Medan Tahun 2017

\section{Tujuan Penelitian}

Untuk mengidentifikasi kejadian infeksi di saluran kemih pada pasien yang sudah terpasang katetersiasi di Ruang Rawat Inap RSU Imelda Pekerja Indonesia (IPI) Medan Tahun 2017.

\section{Manfaat Penelitian}

1. Ruang Rawat Inap RSU Imelda Pekerja Indonesia (IPI) Medan.

Untuk menambah wawasan dan pengetahuan setiap perawat didalam melakukan tindakan kateter dan praktik pencegahan terjadinya infeksi di saluran kemih pada pasien yang terpasang kateterisasi di Ruang Rawat Inap RSU Imelda Pekerja Indonesia (IPI) Medan. 
2. STIKes Imelda MedanSebagai sumber literatur pustaka didalam menambah wawasan pengetahuan mahasiswa dalam bentuk asuhan keperawatan.

3. Peneliti Selanjutnya. Menjadi bahan referensi untuk penelitian selanjudnya yang berhubungan dengan tindakan kateterisasi.

\section{METODE}

\section{Jenis dan Desain Penelitian}

Jenis penelitian yang digunakan dalam penelitian ini adalah studi kasus observasional dengan deskriptif analitik yang bertujuan untuk menganalisis kateterisa si terhadap kejadian infeksi di saluran kemih pada pasien di ruang rawat inap RSU Imelda Pekerja Indonesia (IPI) Medan Tahun 2017

\section{Waktu Penelitian}

Waktu penelitian dilakukan pada bulan April - Mei Tahun 2017.

\section{Populasi}

Populasi diambil dari semua pasien yang terpasang kateter yang dirawat di Ruang Rawat Inap RSU Imelda Pekerja Indonesia (IPI) Medan Tahun 2017 yang berjumlah 13 responden.

\section{Teknik Sampling}

Metode yang digunakan dalam pengamb ilan sample penelitian ini adalah purposive sampling, yaitu metode penetapan sample dengan memilih beberapa sample tertentu yang dimiliki sesuai dengan tujuan atau masalah penelitian dalam sebuah populasi (Nursalam, 2008).

\section{Sampel}

Sampel terdiri dari bagaian populasi terjangkau yang dapat digunakan sebagai subjek penelitian melalui sampling. Sampling adalah proses menyeleksi porsi dari populasi yang dapat mewakili populasi yang ada (Nursalam, 2008). Sample dalam penelitian ini adalah semua populasi yaitu pasien yang terpasang kateter. Kriteria inklusi digunakan untuk menentukan apakah seseorang dapat berpartisipasi dalam studi penelitian atau apakah penelitian individu dapat dimasukkan dalam penelaahan sistematis.

\section{Teknik Pengumpulan Data}

Adapun tahapan prosedur penggumpulan data yang dilakukan, meliputi:

1. Tahap persiapan pengumpulan data

a. Peneliti mengurus surat izin untuk melakukan penelitian dari Progam Studi Sekolah Tinggi Ilmu Kesehata n (STIkes) Imelda Medan.

b. Peneliti mengurus surat izin untuk melakukan penelitian di bagian penel itian dan pengembangan di Ruang Rawat Inap RSU Imelda Pekerja Indonesia (IPI) Medan Tahun 2017.

2. Tahap pengumpulan data dilakukan melalui tahap-tahap sebagai berikut:

a. Peneliti datang langsung ke tempat penelitian dihari yang telah tertera dalam surat yang dikeluarkan oleh bagian pelatihan dan pengembangan di Ruang Rawat Inap RSU Imelda Pekerja Indonesia (IPI) Medan.

b. Peneliti terlebih dahulu memperkenal kan diri dan menjelaskan maksud dari kedatangan peneliti kepada responden (pasien).

c. Meminta kesediaan responden untuk berpartisipasi dalam penelitian

d. Peneliti mengobservasi kateterisasi

e. Peneliti melakukan urinalisa pada pasien yang dipasangi kateter oleh responden.

\section{Variabel Penelitian}

Variabel penelitian adalah karakteristik yang diamati dan mempunyai variasi nilai dan merupakan operasionalisasi dari suatu konsep agar dapat diteliti secara empiris atau ditentukan tingkatannya (Setiadi, 2007).

\section{Defenisi Operasional}

1. Kateterisasi yaitu semua pasien yang terpasang kateter di Ruang Rawat Inap RSU Imelda Pekerja Indonesia (IPI) Medan Tahun 2017. Semua pasien yang terpasang kateterisasi akan dilakukan 
observasi, meliputi lamanya terpasang kateterisasi, ukuran kateter, pemasangan kateterisasi dan perawatan kateterisasi. Dilakukan dengan menggunakan lembar observasi

2. Kejadian infeksi di saluran kemih yaitu kejadian infeksi di saluran kemih yang disebabkan karena lamanya pergantian kateterisasi di Ruang Rawat Inap RSU Imelda Pekerja Indonesia (IPI) Medan Tahun 2017. Kejadian infeksi di saluran kemih yaitu untuk mengetahui berapa jumlah kejadian infeksi di saluran kemih yang terjadi di Ruang Rawat Inap RSU Imelda Pekerja Indonesia (IPI) Medan Tahun 2017. Cara mengetahuinya dengan menggunakan lembar observasi dengan melakukan observasi pada kateterisasi, ukuran kateterisasi, perawatan kateterisasi, dan lamanya pergantian kateterisasi.

\section{Teknik Pengukuran}

Variabel bebas yaitu pemasangan kateter terdiri dari 16 pertanyaan, setiap pertanyaan terdiri dari 2 indikator jawaban "ya" diberi nilai 1; tidak" diberi 0 untuk menghitung skor dengan menggunakan rumus statistik

$$
\mathrm{P}=\frac{\operatorname{Re} n \tan g}{\text { Banyaknya kelas }}
$$

dimana $\mathrm{P}$ merupakan panjang kelas dengan nilai tertinggi dikurangi nilai terendah (Sudjana, 2002) diperoleh rentang sebesar 16, kelas dibagi 2 kategori maka diperoleh panjang kelas 8 , data kuesioner/observasi dikategorikan:

a. "Baik" kumulatif jawaban : 9 - 16 .

b. " Buruk" kumulatif jawaban : 0 - 8 .

Variabel terikat dalam penelitian ini adalah kejadian infeksi saluran kemih yang terdiri dari 7 pertanyaan, setiap pertanyaan terdiri dari 2 indikator jawaban, "ya" diberi nilai 1 ; "tidak" diberi nilai 0. Untuk menghitung total skor dengan menggunakan rumus statistik

$$
\mathrm{P}=\frac{\operatorname{Re} n \tan g}{\text { Banyaknya kelas }}
$$

dimana $\mathrm{P}$ merupakan panjang kelas dengan nilai tertinggi dikurangi nilai terendah (Sudjana, 2002) diperoleh rentang 7, kelas dibagi 2 kategori maka diperoleh panjang kelas 4, data kuesioner/observasi dikategorika n:

a. "Baik" kumulatif jawaban : :4-7

b. " Buruk" kumulatif jawaban : 0-3

\section{Analisa Data}

1. Univariat

Analisis univariat yang digunakan untuk mengetahui karakteristik responden serta distribusi frekuensi kateterisasi dan kejadian infeksi di saluran kemih

2. Bivariat

Analisis bivariat ini digunakan untuk menganalisa kateterisasi terhadap kejadian infeksi di saluran kemih, dengan menggunakan uji chi square dengan $(\alpha) 0,05$ dan tingkat kepercaya an $95 \%$.

HASIL

Tabel. 1 Distribusi frekuensi karakteristik

\begin{tabular}{|c|c|c|c|}
\hline No. & $\begin{array}{c}\text { Karakteristik } \\
\text { Responden }\end{array}$ & $\begin{array}{l}\text { Frekuensi } \\
\text { (f) }\end{array}$ & $\begin{array}{c}\text { Persentase } \\
(\%)\end{array}$ \\
\hline \multirow{3}{*}{1.} & Umur & & \\
\hline & 23 - 32 Tahun & 9 & 69,23 \\
\hline & 33 - 42 Tahun & 4 & 30,77 \\
\hline & Total & 13 & 100 \\
\hline \multicolumn{4}{|c|}{ Pendidikan } \\
\hline \multirow[t]{2}{*}{2.} & Terakhir & \multirow[t]{2}{*}{10} & \multirow{2}{*}{$\begin{array}{l}76,92 \\
23,08\end{array}$} \\
\hline & $\begin{array}{l}\text { D-III } \\
\text { S-1 }\end{array}$ & & \\
\hline & Total & 13 & 100 \\
\hline \multirow{7}{*}{3.} & Lama Bekerja & & \\
\hline & 1-2 tahun & 2 & 15,38 \\
\hline & $2-3$ tahun & 3 & 23,08 \\
\hline & 3-4 tahun & 5 & 38,46 \\
\hline & 4-5 tahun & 2 & 15,38 \\
\hline & 5-6 tahun & 1 & 7,69 \\
\hline & Total & 13 & 100 \\
\hline
\end{tabular}
responden

Dari tabel 1 diatas menunjukkan bahwa umur responden mayoritas 23-32 tahun yaitu $69,23 \%$, pendidikan terakhir mayoritas D-III yaitu $76,92 \%$ dan lama bekerja mayoritas $3-4$ tahun yaitu $38,46 \%$. 
Tabel 2. Distribusi Frekuensi Kateterisasi

\begin{tabular}{clcc}
\hline No & Kateterisasi & $\begin{array}{c}\text { Frekuensi } \\
(\mathbf{f})\end{array}$ & $\begin{array}{c}\text { Persen } \\
(\boldsymbol{\%})\end{array}$ \\
\hline 1. & Baik & 10 & 76,92 \\
\hline 2. & Buruk & 3 & 23,08 \\
\hline & Total & $\mathbf{1 3}$ & $\mathbf{1 0 0}$ \\
\hline
\end{tabular}

Dari tabel 2 diatas menunjukkan bahwa kateterisasi yang dilakukan oleh perawat mayoritas baik sebanyak 10 orang $(76,92 \%)$.

Tabel 3. Distribusi Frekuensi Kejadian Infeksi Saluran Kemih

\begin{tabular}{cccc}
\hline No & $\begin{array}{c}\text { Kejadian } \\
\text { ISK }\end{array}$ & $\begin{array}{c}\text { Frekuensi } \\
(\mathbf{f})\end{array}$ & $\begin{array}{c}\text { Persen } \\
(\mathbf{\%})\end{array}$ \\
\hline 1. & Positif & 2 & 15,38 \\
2. & Negatif & 11 & 84,62 \\
& Total & $\mathbf{1 3}$ & $\mathbf{1 0 0}$ \\
\hline
\end{tabular}

Dari tabel 3 diatas menunjukkan bahwa kejadian infeksi saluran kemih sebanyak 2 orang $(15,38 \%)$, sedangkan 11 orang $(84,62 \%)$ tidak terkena infeksi saluran kemih.

\section{Analisa Bivariat}

Tabel 4. Analisis kateterisasi terhadap kejadian Infeksi Saluran Kemih

\begin{tabular}{cccccc}
\hline & \multicolumn{2}{c}{$\begin{array}{c}\text { Kejadian infeksi } \\
\text { saluran kemih }\end{array}$} & \begin{tabular}{c} 
Chi \\
Total \\
\cline { 2 - 5 } Positif
\end{tabular} & $\begin{array}{c}\text { Square } \\
\text { test }\end{array}$ \\
\hline \multirow{2}{*}{ Kateterisasi } & Baik & 0 & 10 & 10 & \\
\cline { 2 - 5 } & Buruk & 2 & 1 & 3 & 0,005 \\
\hline \multicolumn{2}{c}{ Total } & $\mathbf{2}$ & $\mathbf{1 1}$ & $\mathbf{1 3}$ & \\
\hline \multicolumn{2}{c}{ Dari tabel } & 4 & dapat & dilihat & bahwa
\end{tabular}
pemasangan kateter yang baik yaitu 10 orang dan tidak menyebabkan kejadian infeksi saluran kemih, sedangkan prosedur kateterisasi yang buruk yaitu 3 orang. Dari 3 orang tersebut, 2 orang terinfeksi saluran kemih dan 1 orang tidak terinfeksi saluran kemih.

Dari hasil uji chi-square diatas antara pemasangan kateter dengan kejadian infeksi saluran kemih didapat nilai $\mathrm{P}=0.005(\mathrm{P}$ $<0,05)$ artinya ada hubungan antara pemasangan kateter dengan kejadian infeksi saluran kemih.

\section{PEMBAHASAN}

Dari hasil penelitian yang dilakukan peneliti di Ruang Rawat Inap RSU Imelda
Pekerja Indonesia (IPI) Medan Tahun 2017, akan menguraikan pembahasan penelitian ini yang bertujuan untuk mengetahui hubunga $\mathrm{n}$ analisis kateterisasi terhadap kejadian infeksi di saluran kemih.

Kateterisasi merupakan tindakan memas ukkan selang plastik atau karet melalui uretra ke dalam kandung kemih (Potter \& Perry, 2005). Pemasangan kateter semakin lama akan menurunkan sebagian besar daya tahan alami pada traktus urinarius inferior dengan menyumbat duktus periuretra lis, mengiritasi mukosa kandung kemih dan menimbulkan jalur artifisial untuk masuknya kuman (mikroba patogen) ke dalam kandung kemih (Smeltzer \& Bare, 2001). Kemudian mikroba patogen tersebut akan berkembang biak maka akan mengakibatkan kerusakan serta gangguan fungsi organ semakin luas yang akhirnya memunculkan manifestasi klinis yang signifikan untuk diagnosis infeksi saluran kemih (Darmadi, 2008).

Saluran kemih adalah tempat yang paling sering mengalami infeksi nosokomial. Pemasangan kateter dan lamanya dipasang sangat mempengaruhi kejadian terjadinya infeksi saluran kemih, tetapi tidak semua klien yang dipasang kateter mengalami infeksi saluran kemih (Tessy, 2004). Barbara \& Smeltzer (2001) menyatakan bahwa infeksi saluran kemih menempati tempat ke-3 dari infeksi nosokomial di rumah sakit $80 \%$ dari infeksi saluran kemih disebabkan oleh kateter uretra. Infeksi saluran kemih setelah pemasangan kateter terjadi karena kuman dapat masuk ke dalam kandung kemih dengan jalan berenang melalui lumen kateter, rongga yang terjadi antara dinding.kateter dengan mukosa uretra, sebab lain adalah bentuk uretra yang sulit dicapai oleh antiseptik. Sehingga pasien yang mengalami infeksi saluran kemih akibat pemasangan kateter akan mendapatkan perawatan yang lebih lama dari yang seharusnya sehingga biaya perawatan akan menjadi bertambah dan masalah ini juga dapat memperburuk kondisi kesehatan klien, bahkan dapat mengancam keselamatan 
jiwanya. Tindakan yang dapat dilakukan perawat untuk mencegah terjadinya infeksi saluran kemih pada pasien yang terpasang kateter adalah dengan melakukan higiene perineum, perawatan kateter, pemant auan drainase urin dan memberikan informasi kesehatan kepada pasien tentang hal-hal yang dapat mendukung kelancaran drainase urin yang sekaligus akan mencegah terjadinya infeksi pada saluran kemih.

Berdasarkan hasil penelitian pada tabel 3 diketahui bahwa 11 pasien $(84,62 \%)$ yang dilakukan pemasangan kateter dengan baik oleh responden tidak mengalami infeksi saluran kemih dan hanya 2 pasien $(15,38 \%)$ yang mengalami infeksi saluran kemih. Hasil penelitian ini sejalan dengan teori yang dikemukakan oleh Sudoyo (2006) bahwa dipasangnya kateter sangat mempenga ruhi kejadian infeksi saluran kemih. Dipasang 1 kali menyebabkan infeksi 1,7\%, intermitten 3,5\%, sedangkan bila dipasang dower kateter sebanyak $10 \%$. Pemasangan kateter pada sistem terbuka kejadian demam lebih sering daripada sistem tertutup.Bila kateter dipasang selama 2 hari infeksi dapat terjadi $15 \%$, bila 10 hari menjadi $50 \%$. Penelitian yang dilakukan oleh Putri dkk (2011) tentang "Faktor Faktor Yang Berpengaruh Terhadap Kejadian Infeksi Saluran Kemih Pada Pasien Rawat Inap Usia 20 Tahun Ke Atas Dengan Kateter Menetap di RSUD Tugurejo Semarang".Dalam hasil penelitian ini diperoleh ada pengaruh antara lama penggunaan kateter dengan kejadian Infeksi Saluran Kemih pada pasien yang menggunak an kateter menetap ( $\mathrm{p}$ value $=0,005)$ artinya pasien dengan lama penggunaan kateter >3 hari memiliki peluang untuk mengalami infeksi saluran kemih dibandingk an dengan pasien yang menggunakan kateter $<3$ hari, ada pengaruh antara perawatan kateter dengan kejadian Infeksi Saluran Kemih (ISK) pada pasien yang menggunakan kateter menetap.

Menurut peneliti berdasarkan teori dan hasil penelitian terkait diatas maka dapat disimpulkan bahwa terdapat hubungan antara pemasangan kateter dengan kejadian infeksi saluran kemih hal ini disebabkan karena pemasangan kateter yang kurang baik sehinggaakan memudahkan mikroorgani sme untuk masuk kedalam sistem perkemihan yang menyebabkan terjadinya infeksi. Hal ini dapat dicegah tentunya dengan teknik pemasangan kateter yang aseptik serta perawatan kateter yang baik.Seseuai dengan teori yang dikemukakan oleh Potter \& Perry (2005) bahwa perawatan kateter adalah suatu tindakan keperawatan dalam memelihara kateter dengan antiseptik untuk membersihkan ujung uretra dan selang kateter bagian luar serta mempertahan kan kepatenan kelancaran aliran urin pada sistem drainase kateter. Pasien yang dik ateterisasi dapat mengalami infeksi saluran kemih melalui berbagai cara. Perawat an kateter merupakan tindakan yang penting untuk mengontrol infeksi. Perawatan kateter yang salah dapat menyebabkan masuknya mikroorganisme. Daerah yang memiliki resiko masuknya mikroorganisme ini adalah daerah insersi kateter, kantung drainase, sambungan selang, klep, dan sambungan antara selang dan kantung.

\section{KESIMPULAN}

Berdasarkan hasil penelitian yang telah dilakukan peneliti mengenai analisis kateterisasi terhadap kejadian infeksi di saluran kemih pada pasien di ruang rawat inap RS Imelda Medan Tahun 2017 dapat di simpulkan bahwa :

1. Kateterisasi yang dilakukan oleh perawat mayoritas baik sebanyak 10 orang $(76,92 \%)$.

2. Kejadian infeksi saluran kemih sebanyak 2 orang $(15,38 \%)$, sedangkan 11 orang $(84,62 \%)$ tidak terkena infeksi saluran kemih.

3. Hasil uji chi-square diatas antara pemasangan kateter dengan kejadian infeksi saluran kemih didapat nilai $\mathrm{P}=$ $0.005(\mathrm{P}<0,05)$ artinya ada hubungan antara pemasangan kateter dengan kejadian infeksi saluran kemih. 


\section{DAFTAR PUSTAKA}

Brooks, Geo F. (2007). Mikrobiologi Kedokte ran Jawetz, Melnick \& Adelberg / Geo F. Brooks, Janets S. Butel, Stephen A. Morse,; Alih Bahasa, Huriawati Hartant o...[et. al.]; editor edisi bahasa Indonesia, Retna Neary Elfira..[et.al.] ed. 23. Jakarta:. EGC.

Brunner \& Suddarth, (2008). Keperawatan Medikal Bedah. Edisi 8. Jakarta: EGC.

Ellis, et all. (1996). Modules for Basic Nursing Skills. Philadelphia: : Lippincott.

Gruendemann BJ, Fernsebner B. (2005). Buku Ajar Keperawatan Perioperatif. Vol. 1. Jakarta: EGC.

Hotoon, T.M,. [et.al]. (2010). Diagnosis, Prevention and Treatmen oa Catheter As sociated Urinary Tract Infection In Adults: 2009 Internasional Clinical Practice Guidelines from the Infectious Disease Sosiety of America, Guideline s catheterUrinary.

Kozier, B., Erb, G., Berman, A., Synder, S.J. (2010). Buku ajar keperawatan fundam ental (Esty wahyuningsih, penerjemah). Jakarta: EGC.

Makic, M.B., Vonrueden, K. T., Rauen, C.A., \& Chadwick, J. (2011). Evidence Based Practice Habits: Putting more sacret cows out to pasture. critical care nurse. Vol 31. No.2. 38-61.

Meyer, D.J. Harvey J.W. (2004). Veterinary Laboratory Medicine Interpretation and Diagnosis. Philadelphia: Saunders.

Murwani (2009). Pedoman Kateterisasi urin. Edisi revisi. Jakarta : EGC.
Nursalam. (2008). Konsep dan penerapan metodologi penelitian ilmu keperawatan pedoman skripsi, tesis, dan istrumen pe nelitian keperawatan. Jakarta: Salemba Medika.

Notoatmodjo, (2010). Metodolog penelitian kesehatan edisi Revisi. Jakarta: Rineka Cipta.

Potter \& Perry, (2005). Fundamental of nursing. $\left(7^{t n}\right.$ ed) Mosby: Elsevier Inc.

Samad, R. (2012). Hubungan Pemasangan Kateter Dengan Kejadian Infeksi Saluran Kemih Pada Pasien Di Ruang Rawat Inap Penyakit Dalam Rsudza Banda Aceh Tahun 2012.

Suharyanto, dan Madjid. (2009). Asuhan keperawatan pada klien dengan gangguan sistem perkemihan. Jakarta: TIM.

Rendy dan Margareth. (2012). Asuhan Keperawatan Medikal Bedah dan Penyakit Dalam. Yokyakarta: Nuha Medika.

Tessy Agus, Ardaya, Suwanto. (2001). Buku Ajar Ilmu Penyakit Dalam: Infeksi Saluran Kemih. Edisi: 3. Jakarta: FKUI.

Tietjen, L., Bossomeyer, D., \& Noel, M. (2004). Panduan pencagahan infeksi unt $u k$ fasilitas pelayanan kesehatan dengan sumber daya terbatas. Alih bahasa: Abdul Bari Syaifuddin. Jakarta: Yayasan Bina Pustaka Sarwono Prawirohardjo.

Tuzker, S.M., [et.al). (1998). Patiend Care Standards : Nursing process, diagnosis, and autcome). California: Mosby Inc. 